\title{
SHAKESPEARE AS A CELEBRITY ENDORSER: THE USE OF THE BARD IN CONTEMPORARY ADVERTISING PRACTICES
}

\author{
Okutman Sadık ÇALIŞKAN ${ }^{* 1}$ \\ *Inönü Üniversitesi, Yabancı Diller Yüksekokulu, Malatya ,Türkiye
}

\begin{abstract}
It is a well established fact that Shakespeare influenced modern day literature and the English language more than any other writers, and ubiquitous nature of him can be perceived in our daily lives from radio and television to music, from art to video games. Advertising, which is also a word invented by the Bard, is one of the branches in which Shakespeare's influence is recognized. What Shakespeare represents for the modern world have prompted advertisers to use the Bard as their focus in advertising. Besides being recognized as a symbol of romance, Shakespeare is depicted as the ideal man. He is depicted as a genius, a man with the skill of wordplay, a playwright of timeless nature which makes him a high class man who can persuade people to appreciate brands or purchase goods or services by brands. Shakespeare's universality has been a significant factor for advertisers to exploit his image or language in advertisements. Throughout modern advertising history, since the publisher, Jacob Tonson, based his trademark on the Chandos portrait, the various elements such as scenes from his plays, his famous quotes, sonnets, the name of characters in his plays even his name or portrait have been used by manufacturers, suppliers and service providers. The aim of the study is to show Shakespeare's influence on advertising through ad examples of brands from printed media, broadcasting media and interactive media.
\end{abstract}

Key Words: Shakespeare, advertising, celebrity endorsement

\section{SHAKESPEARE'IN ÜNLÜ BIIR ŞAHSIYET OLARAK REKLAMLARDA KULLANIMI}

Özet

Shakespeare'in günümüz edebiyatını ve İngilizce dilini diğer yazarlardan daha fazla etkilediği ve onun zaman ve mekan üstü doğasının radyo ve televizyondan müziğe, sanattan video oyunlarına kadar günlük hayatımıza nüfuz ettiği iyi bilinen bir gerçektir. Shakespeare tarafından icat edilen bir kelime olan reklam Shakespeaere'in etkisinin hala etkisi olan dallardan biridir. Shakespeare'in modern dünya için ifade ettiği anlam, reklamverenlerin kendisini reklamcılıktaki odak noktası olarak kullanmalarına neden olmuştur.Romantizmin bir sembolü olarak tanınmasının yanı sıra, Shakespeare reklamcılar ratafından ideal insan olarak betimlenmiştir. Onun bir deha, kelime oyunu yeteneğine sahip bir adam, zamansız doğanın bir oyun yazarı olması onu tüketicileri belli marka, ürün ya da hizmetleri satin almak konusunda ikna etmek konusunda yüksek sınıf bir insan yapar. Shakespeare'ın evrenselliği de onun imajından ya da dilinden yararlanmak isteyenler reklam verenler için önemli bir etken olmuştur.Modern reklamcılık tarihi boyunca, yayıncı Jacob Tonson,'dan beri Shakespeare'in oyunlarından sahneler, ünlü sözleri, sonneleri, oyunlarındaki karakterler, adı ve hatta portresi gibi çeşitli unsurlar üreticiler, dağıtıcılar ve reklamcılar tarafından kullanılıştır.Bu çalışmanın amacı, basıı medya, Tv reklamı, ve interaktif ortamlardaki reklam örnekleri ile Shakespeare'in reklamcllık üzerindeki etkisini ortaya koymaktır.

Anahtar Kelimeler: Shakespeare, Reklamcılık, Ünlü Kullanımı

\section{Introduction}

Ben Jonson anticipated Shakespeare's fabulous legacy when he declared, "He was not of an age, but for all time!" in the preface to the First Folio. Today Shakespeare is an industry, an era in time, a symbol of literature and art. In contemporary advertising world he is also a celebrity who writes, directs and acts in commercials.

\footnotetext{
${ }^{1}$ Yazar mail adresi: sadik.caliskan@inonu.edu.tr
} 
Advertising is a means of communication with the users of a product or service. Advertisements are messages paid for by those who send them and are intended to inform or influence people who receive them, as defined by the Advertising Association of the UK. (Arens, 2004) Advertising deals in already familiar cultural myths, and so it tends to be a carrier and intensifier of received ideas, although it may certainly create compelling new styles for presenting them.

The characteristics of advertising are known by many. However, what most people do not know about advertising is that the term was first used by Shakespeare. As the inventor of 1700 common words in the English language, Shakespeare used the term for the first time in the play Measure for Measure (Whynot, 2013).

VINCENTIO: Come hither, Isabel. Your friar is now your prince: as I was then Advertising and holy to your business, Not changing heart with habit, I am still Attorney'd at your service. -(Measure for Measure, Act 5, Scene 1, Line 410)

One of the most popular advertising techniques worldwide is to have a celebrity endorse a product. Celebrity endorsement is usually only a part, but an important part, of a larger product marketing campaign. In addition to being well known and famous, celebrities are attractive, likeable, and trustworthy at least in the minds of the public to whom the advertising message is directed. The hope is that the celebrities' qualities will be "transferred" in some way to a product and stimulate sales. At this point not only Shakespeare himself but also the characters he invented become important in the promotion of products.

Shakespeare is the best-selling author of all time; his book sales estimated between two and four billion. There have been more than 400 feature length films and TV productions of Shakespeare works. There are currently 67 registered trademarks bearing Shakespeare's name the UK ranging from Shakespeare's Pies to the Royal Shakespeare Company (Campaignbrief, 2012). Due to association with Shakespeare, each year Stratfordon-Avon district is visited by about 5 million people generating $£ 335$ million contribution to local economy which supports over 8000 jobs. According to research evaluating the monetary worth of historical figures by the brand valuation firm Brand Finance, William Shakespeare as a name is estimated to be worth a $\$ 600$ million. (Brandfinance, 2016)

\section{Literature review}

The connection between Shakespeare and advertising began when the publisher, Jacob Tonson, based his trademark on the Chandos portrait. Since then there have been many examples in which Shakespeare used as a celebrity endorser.

Although there are some early examples from 17th and 18th century, the golden age of Shakespeare in advertising is between 1875 to 1900 in which people witnessed the rise of mass produced and mass distributed commodities. As these industrially produced goods displace items that households would previously have made themselves, those new products needed symbolic associations and reassurances about quality that would encourage consumers to integrate them into their lives (Kinney, 2011:501)

In their pursuit of encouraging customers to integrate mass produced commodities into their lives and convincing a sceptical public of those goods' quality, Shakespeare proved useful. There were Cordelia sofas, Romeo and Juliet tobacco, Antony and Cleopatra cigars, Othello dresses, Hamlet stoves etc. Shakespearean names gave goods an air of quality and familiarity. Moreover advertisers chose Shakespeare's lines so that Shakespeare himself and his texts seemed to endorse the product (Rutter,2007). From 1900 to 1960s, Shakespeare themed marketing declined noticeably. During that period Shakespeare's face was occasionally used as a logo and a few citations appeared in ads. The reason for using Shakespeare less often can be attributed to many factors. The emergence of pronounced cultural divide between highbrow and lowbrow, with Shakespeare increasingly coded as high culture meant that Shakespeare could no longer be deployed as a voice of popular authority in advertising. The cultural division between Shakespeare and popular culture was widened by films, radio's and television's displacement of the theatre as the dominant medium for performance. As a symbol of traditionalism, elitism, and specialist knowledge, Shakespeare had lost the common touch (Kinney, 2012:503)

Since 1990s, due to successful films, TV Shows and popular books about Shakespeare, he has become more than a celebrity with different characters and themes for the advertisers who would like to address more globalized consumers who know his plays, love his sonnets and characters. Although Shakespeare themed 
ads make up quite a small segment of advertising as a whole, when celebrity endorsement is taken into consideration, they can be seen as a rare example in which a celebrity is used in an unusual way.

\section{Data and methodology}

In this study we were able to detect 102 commercials from traditional and digital media. The time period of ads range from 1990 to 2018. The ads were obtained from the British Universities Film \& Video Council (BUFV) database and www.adsoftheworld.com. We tried to find the common themes, the type of associations with Shakespeare, and relevant industries.

In a few print commercials, his portrait or his name along with his quotes are used as a symbolic connection to promote the product. In others, characters such as Hamlet, Othello, Romeo and Juliet, Marcus Brutus, lines or scenes from the plays are used. The most appealing play for the advertisers is Romeo and Juliet with romantic love and passion or struggling with society. $30(30 \%)$ of the ads have references to Romeo and Juliet. Romeo courting Juliet in the balcony scene have been used many times, Hamlet is nearly as common as Romeo and Juliet. Hamlet holds Yorick's skull 11 times and variations of "to be or not to be" are used 18 times in commercials.

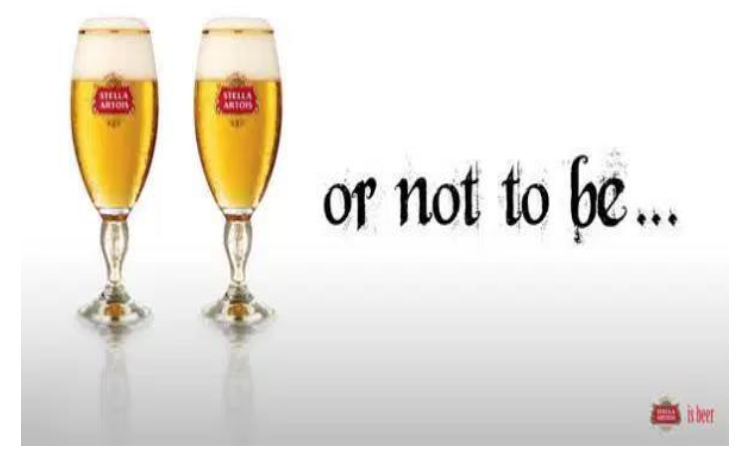

Figure 1. Stella Artois Beer Commercial

When we look at the industries in which Shakespeare is used, the ads are as diverse as his characters. Although globalization of Shakespeare by films, his close identification with Anglo culture has diminished and his link to urban youth culture worldwide has strengthened. The ads are not only from England or the West but also from China, Japan, India, Poland, South Africa, Brazil etc. Shakespeare themed ads can be about any item such as beds, ice creams, pizza, refrigerators, condoms, post it notes etc.

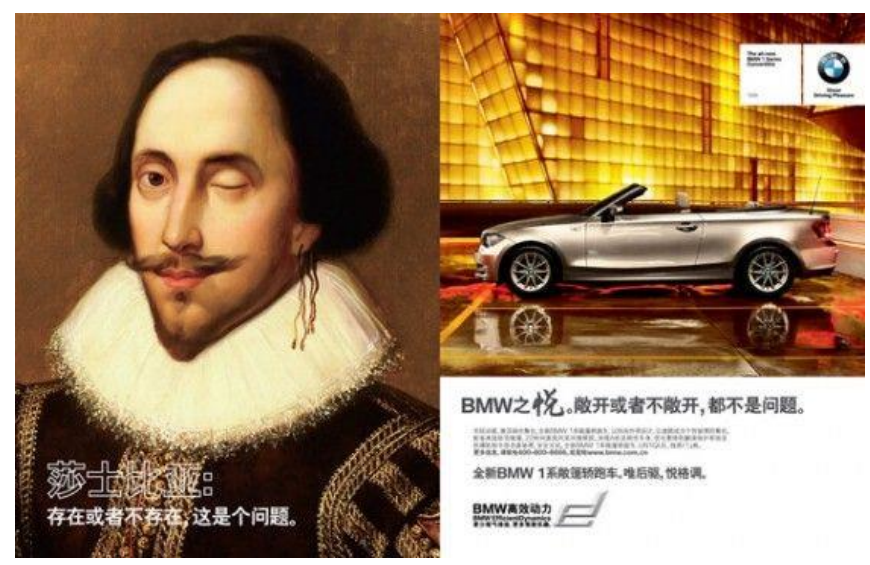

Figure 2. Chinese BMW Commercial

Although there is a diversity of ads, we have found three main industries in which Shakespeare is used for promoting the products and giving them a sense of quality and prestige. These are automobile, drink \&tobacco, and communication industries. 


\subsection{Automobile Industry}

In the highly competitive car market, it is technologically possible for different manufacturers to produce very similar products, therefore it is crucially important for each firm to provide reasons for the consumers to prefer its own brand. Attractive price or financial conditions may not be enough to persuade consumers to buy as they are more than a means of transport. They are objects representing certain aesthetic and cultural values and they have long been seen as symbols of one's wealth, taste, style and every car is to some extend aspirational, so it is not surprising to see Shakespeare in automobile marketing in an attempt to promote products by emphasizing prestige and status. The German Automobile manufacturer BMW promoted its new model with the adaptation of Shakespeare's famous quote" to be or not to be" in China. Another German automobile company Mercedes uses Shakespeare's signature with the slogan "Unlike any other" to inform American customers about the uniqueness of their cars and give a luxurious and prestigious feeling (Hodsic, 2007)

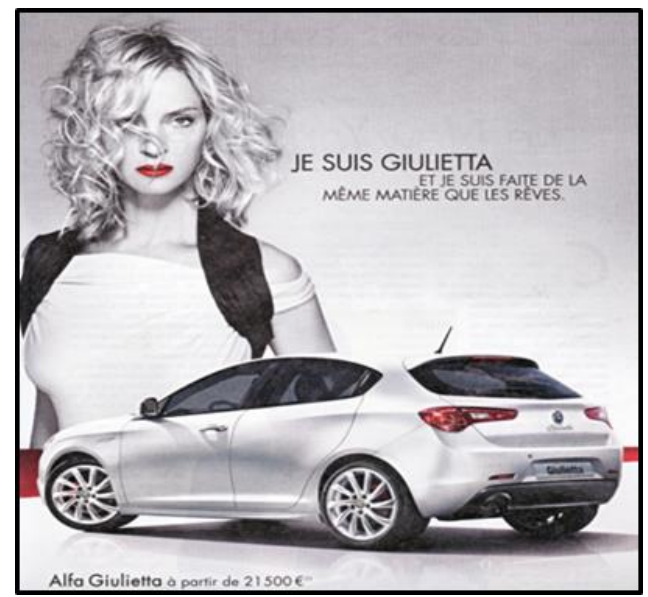

Figure 3. Giulieta Commercial

Romeo and Juliet are back together again at last, in an ad for Alfa Romeo's new car called the Giulietta. The Giulietta is a revived model name first used by Alfa Romeo from 1954-1965.

In an ad for Alfa Romeo's new model called Giulietta, a car model in which Shakespeare's Romeo and Juliet come together, Hollywood film star Uma Thurman and Shakespeare combined their forces. The name Giulietta is the orininal form of the name Juliet and a revived model name which was first used by Alpha Romeo from 1954 to 1965. In the ad which was shown in different European countries, Thurman talks with a hushed voice accompanied by an attractive music. She identifies herself as Giuletta which leads the audience to imagine that it is the car speaking. The actress' personalities are reflected in the features of the car visually and they ultimately merge into the same entity. References starting from a dream-like, abstract dimension are resolved in an urban context, attributing realism and consistency to Giulietta's dream. The ad uses the quote "We are such stuff as dreams are made on" which is not from Romeo and Juliet but a line of Prospero in the play The Tempest. The slogan "Without heart we are only machines" counterbalances the Shakespeare quote and they confirm the feeling and mood that the advertisement reinforces - that the new Alfa Romeo Giulietta is a car that would seem to be a dream but in fact is a reality.

\footnotetext{
"Our revels now are ended. These our actors, As I foretold you, were all spirits and Are melted into air, into thin air:

And, like the baseless fabric of this vision, The cloud-capp'd towers, the gorgeous palaces,

The solemn temples, the great globe itself, Ye all which it inherit, shall dissolve And, like this insubstantial pageant faded, Leave not a rack behind. We are such stuff As dreams are made on, and our little life Is rounded with a sleep. Sir, I am vex'd; Bear with my weakness; my, brain is troubled:
} 
Be not disturb'd with my infirmity:

If you be pleased, retire into my cell

And there repose: a turn or two I'll walk,

To still my beating mind". (4.1.146-163)

In their ad campaign called the Art of Villainy, British car company Jaguar uses the image of British bad characters in Hollywood films. While focusing on its British character, using Shakespeare's lines from Richard II generate a parallelism between the brand and England. In the ad Tom Hiddleson who is well known for playing King Henry V in a TV series is driving in a white Jaguar while listening to the lines from Richard II. Tom abruptly turns it off and turns to the camera to deliver a monologue of his own. He accepts a mysterious bag makes a fast gate away from the police while explaining "What makes a great villain" which is shown as the follow up of Shakespeare's lines. In order to generate integrity the commercial ends with the monologue from Richard II

This royal throne of kings, this sceptred isle,

This earth of majesty, this seat of Mars,

This other Eden, demi-paradise,

This fortress built by Nature for herself

Against infection and the hand of war

And ends with

This happy breed of men, this little world,

This precious stone set in the silver sea,

Against the envy of less happier lands,

This blessed plot, this earth, this realm, this England.

It's all mine!

As in the Alfa Romeo commercial, a link is generated between the actor as a typical British villain and Jaguar. They try to create congruency between the villains' values and the car attributes.

\subsection{Tobacco and Beverage Industry}

A notable number of ads are related to drink and tobacco. It is a well-established fact that tobacco and beverage companies advertise their products as "sophisticated pleasure" Traditionally seen as the epicentre of the English literary tradition and viewed as an original genius, Shakespeare has become a marker of cultural sophistication. Thus, simply by suggesting a link between their products and the famous playwright, tobacco and beverage companies are able to market their cigars and cigarettes or beverages as representative of high culture.

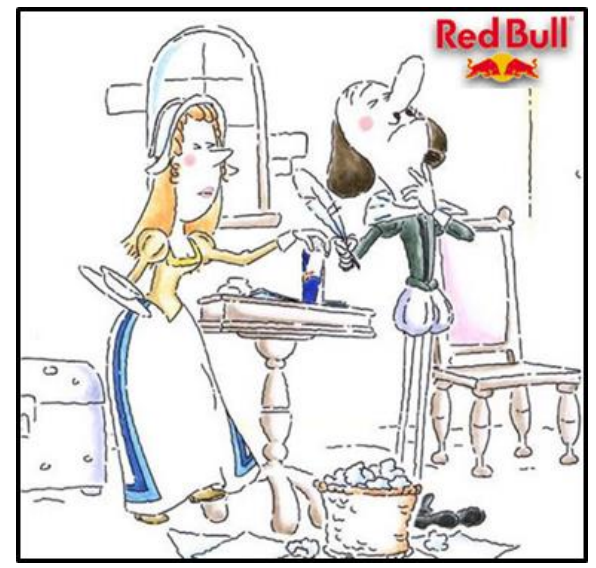

Figure 4. Red Bull TV Commercial (2015)

In Energy drink company Red Bull' campaign called "Red Bull gives you Wings" which is in a cartoon form, featuring the voice over of Shakespearean actor Brian Blessed. Shakespeare is taking a drink from a can of 
Red Bull as he fluently composes lines for his latest play Hamlet, then running out of inspiration when a maid tidies the can away. Tag line is 'Genius will suffer without Red Bull'.

The beverage company Gordon's TV commercial portrays two characters playing a game and quoting different Shakespeare plays and drinking Gordons Gin while waiting for a play to start. The advert uses a number of different devices to accomplish its campaign. The characters are presented as people to aspire to, they appear intelligent, cultured people who are quoting Shakespeare, this gives the impression to the audience that they should be too. Attaching the iconic quotes from King Lear or Hamlet adds positive connotations to their brand, they appear sophisticated and expensive. Furthermore, the advert does not exclude people hindered by social or economic boundaries, referencing a popular footballer, Eric Cantona.

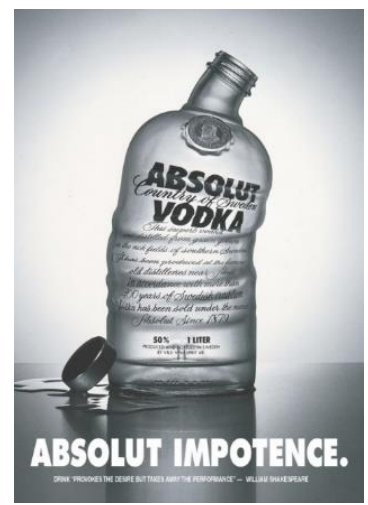

Figure 5. Absolute Print Commercial

Shakespeare's words have also been used to deter people from drinking. In this example of spoof advertising against alcoholism called Absolut Impotence the advertisers use a quote from Shakespeare "Drink provokes the desire but takes away the performance." from Macbeth, and it gives consumers an idea about the negative effects of alcohol.

\subsection{Communication Industry}

An area in which Shakespeare is overwhelmingly used is communication and technology. Mobile phone companies such as Nextel, T Mobile, Orange, At\&t or Apple have all referred to Shakespeare in their commercials. The main reference point of the advertisements is Romeo and Juliet, which seems a perfect example of miscommunication. They add humour to the text to create comedyout of tragedy in the commercial videos. In Orange commercial, there are red roses, longing looks of the actors. The background music is from Franco Zeffirelli's 1968 dated film Romeo and Juliet. It creates a romantic atmosphere with the combination of Shakespearean elements.

In Nextel's 2003 ad campaign promoting "push to talk" mobile phones, a thirty second version of Romeo and Juliet includes all of the tragic accidents and events that befell the characters in the actual play. Each participant clasps a phone and speaks his or her line in a brief and telegraphic way. References to Romeo and Juliet appear in Nextel ad for telecommunication services; it is ironic given that the lack of communication is what instigates the tragedy of the play.

In BBC's new season ad (2014), Benedict Cumberbatch, who is known as a Shakespearean actor, recites the famous "seven ages of man" monologue from As you like it, starting with "All the world is a stage" accompanied with memorable moments from the channel. For the ITV's promotional ad for "Coronation Street and Emmerdale, actors recite lines from Sonnet 18 in an afford to connect the soap operas with Shakespeare's romance.

"Shall I compare thee to a summer's day?

Thou art more lovely and more temperate: Rough winds do shake the darling buds of May, And summer's lease hath all too short a date: Sometime too hot the eye of heaven shines,

And often is his gold complexion dimm'd; And every fair from fair sometime declines, 
By chance, or nature's changing course, untrimm'd;

But thy eternal summer shall not fade

Nor lose possession of that fair thou ow'st;

Nor shall Death brag thou wander'st in his shade,

When in eternal lines to time thou grow'st;

So long as men can breathe or eyes can see,

So long lives this, and this gives life to thee." (Shakespeare, 2000)

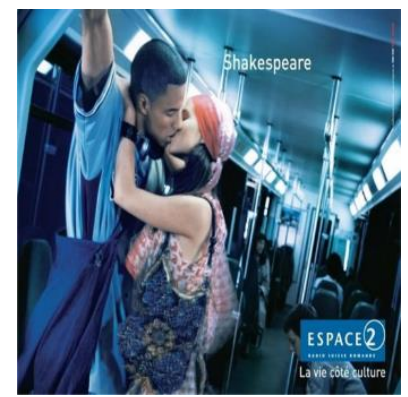

Figure 6. Espace 2 Commercial

In a print ad for a Swiss radio station, Espace 2 we are shown two lovers kissing in the tube. Most of people with limited knowledge on what Shakespearean drama are all about often associate them with romance. His version of romance is especially in Romeo and Juliet, passionate, instantaneous, and powerful. The image can be paralleled to Othello in the sense that interracial context is applied

\title{
4. Conclusions and implications
}

As a conclusion we can say that Shakespeare, and the things related to Shakespeare add familiarity or prestige to anything associated to his name and therefore used by a lot of organisations for commercial purposes. Although the effect declined dramatically in the first three quarters of 20th century, for the last three decades there has been great interests from marketers to use him as a promoter of the goods due to his popularity with reproduction of plays, films and books. Due to universality of his plays and characters and being a world famous celebrity, he is still a monument that advertisers would like to take advantage of.

As Shakespeare (2000) mentioned in his 55th. Sonnet, his writings could last when other things wouldn't. His "powerful rhyme" would be eternal which is sure to be used by advertisers in the future.

\author{
Not marble, nor the gilded monuments \\ Of princes, shall outlive this powerful rhyme; \\ But you shall shine more bright in these contents \\ Than unswept stone, besmear'd with sluttish time. \\ When wasteful war shall statues overturn, \\ And broils root out the work of masonry, \\ Nor Mars his sword nor war's quick fire shall burn \\ The living record of your memory. \\ 'Gainst death and all-oblivious enmity \\ Shall you pace forth; your praise shall still find room \\ Even in the eyes of all posterity \\ That wear this world out to the ending doom. \\ So, till the judgment that yourself arise, \\ You live in this, and dwell in lovers' eyes.
}

\section{References}

1. Arens, W. F. (2004). Contemporary advertising. Tata McGraw-Hill Education.

2. Garber, M. (2009). Shakespeare and modern culture. Anchor.

3. Hodzic, M. (2007). Mercedes Ad: Unlike any other, Benzinsider Magazine

4. Kinney, A. F. (Ed.). (2011). The Oxford Handbook of Shakespeare. OUP Oxford. 
5. Rutter, C. C. (2007). Shakespeare's popular face: from the playbill to the poster. na.

6. Shakespeare, W. (2000). Shakespeare's sonnets. Yale University Press.

7. Shakespeare, W., \& loppolo, G. (2017). Measure For Measure: The Folio of 1623. Routledge.

8. Shakespeare, W., \& Hinman, C. (1996). The first folio of Shakespeare. WW Norton \& Company.

9. Shakespeare, W. (2000). Shakespeare's sonnets. Yale University Press.

10. Whynot, T. (2013). Shakespearean Dictionary. YA Hotline, (95).

\section{Internet References}

1. Brandfinance, (2014) Shakespear Brand Value US $\$ 600$ Million - CNN (http://brandfinance.com/news/shakespear-brand-value-us600-million-cnn/) Erişim Tarihi: 2018

2. https://www.youtube.com/watch?v=KnSrng9pS5Q

3. Mills, C. (2014) How Has Shakespeare Influenced Modern Marketing? (https://parall.ax/blog/view/3046/how-has-shakespeare-influenced-modern-marketing-)

4. Campaignbries (2012) Shakespeare's brand worth valued at $\$ 600$ million - double the combined value of Elvis and Marilyn (http://www.campaignbrief.com/2012/03/version10-starthtml0000000149-176.html)

5. Nosweat, (2014)What's in a Name? The Shakespeare Brand in the World of Commerce (https://www.nosweatshakespeare.com/blog/shakespeare-branding/)

6. Gilroy, D., (2010) BMW China: Darwin, Newton, \& Shakespeare Launch The 1 Series (http://advertising.chinasmack.com/2010/bmw-darwin-newton-shakespear-launch-1-series.html)

7. Laurengus17, (2011) Studying Shakespeare beyond his text https://transmedialshakespeare.wordpress.com/2011/03/15/shakespeare-in-advertising-2/

8. https://www.adsoftheworld.com

9. http://bufvc.ac.uk/

10.https://www.youtube.com/watch?v=RMDe3VM0 eM

11. https://www.youtube.com/watch?v=5IEXQeGq3WU

12. https://www.youtube.com/watch?v=KnSrng9pS5Q 